\title{
Pengaruh Ukuran Perusahaan, Penerapan Good Corporate Governance, dan Pengungkapan Corporate Social Responsibility pada Nilai Perusahaan
}

\author{
Rivandi Pradana ${ }^{1}$ \\ Fakultas Ekonomi dan Bisnis \\ Universitas Udayana, Indonesia. \\ Email: rivandipradana@yahoo.com
}

\author{
Ida Bagus Putra Astika ${ }^{2}$ \\ Fakultas Ekonomi dan Bisnis \\ Universitas Udayana, Indonesia.
}

\begin{abstract}
ABSTRAK
Sebuah perusahaan ketika didirikan telah memiliki tujuan yang ingin dicapai. Untuk mencapai tujuan tersebut diperlukan respon positif dari berbagai pihak. Respon positif ini cenderung didapat perusahaan memiliki nilai perusahaan yang baik. Untuk mengetahui bagaimana pengaruh ukuran perusahaan, penerapan GCG dan pengungkapan CSR pada nilai perusahaan merupakan tujuan dari penelitian ini. Semua perusahaan yang terdaftar di BEI selama periode 2013-2016 dan termasuk dalam sektor perusahaan manufaktur merupakan populasi dari penelitian. Sampel yang didapatkan setelah menggunakan metode purposive sampling adalah sebanyak 41 sampel. Regresi linier berganda adalah teknik analisis yang digunakan. Dari hasil penelitian ini dapat ditarik kesimpulan bahwa variabel ukuran perusahaan dan penerapan GCG berpengaruh positif pada nilai perusahaan, sedangkan untuk pengungkapan CSR tidak berpengaruh pada nilai perusahaan.
\end{abstract}

Kata Kunci : Nilai perusahaan, ukuran perusahaan, corporate governance perception index, corporate social responsibility, bursa efek Indonesia.

\section{Effect of Company Size, Implementation of Good Corporate Governance, and Disclosure of Corporate Social Responsibility on Company Value}

\section{ABSTRACT}

A company when it is established has a goal to be achieved. To achieve this goal a positive response from various parties is needed. This positive response tends to get the company to have good corporate value. To find out how the influence of company size, the application of GCG and disclosure of CSR on company value are the objectives of this study. All companies listed on the IDX during the 2013-2016 period and included in the manufacturing company sector are the population of the study. Samples obtained after using purposive sampling method were as many as 41 samples. Multiple linear regression is the analytical technique used. From the results of this study it can be concluded that the variable size of the company and the application of GCG have a positive effect on firm value, while for disclosure of CSR does not affect the value of the company.

Keywords: Corporate Value, Company Size, Corporate Governance Perception Index, Corporate Social Responsibility, Indonesia Stock Exchange.

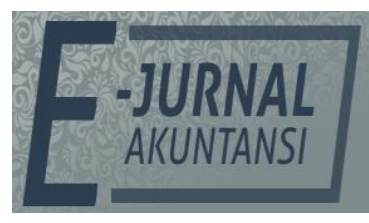

E-JA

e-Jurnal Akuntansi e-ISSN 2302-8556

Denpasar, Vol. 28 No. 3

September 2019

Hal. 1920-1933

Artikel masuk: 25 Juni 2019

Tanggal diterima: 02 September 2019 


\section{PENDAHULUAN}

Perusahaan ketika didirikan telah memiliki tujuan yang ingin dicapai. Salah satu tujuan dari perusahaan adalah mencapai nilai perusahaan yang maksimal (Harjito \& Martono, 2005). Ketika perusahaan mampu memaksimalkan nilai perusahaan, maksimalnya nilai perusahaan akan berdampak pada kemakmuran dari perusahaan tersebut (Brigham \& Housten, 2011).

Keuntungan dari perusahaan merupakan salah satu faktor yang dapat dijadikan dasar dalam menentukan nilai suatu perusahaan (Puspaningrum, 2014). Dalam meningkatkan nilai perusahaan, terdapat beberapa hal yang harus diperhatikan oleh perusahaan yaitu ukuran perusahaan good corporate governance dan corporate social responsibility (Nandasari, 2009).

Total aset dari suatu perusahaan menjadi tolak ukur dari ukuran perusahaan. Ketika suatu perusahaan tersebut memiliki total aset dalam jumlah yang besar maka perusahaan tersebut termasuk dalam perusahaan yang ukuranya besar. Ketika suatu perusahaan memiliki total aset yang sangat kecil maka perusahaan tersbut dikategorikan sebagai perusahaan yang berukuran kecil. Perusahaan dengan total aset yang berjumlah besar memiliki pertimbangan mengenai penggunaan dananya yang diharapkan kedepannya dapat memberikan efek positif pada nilai perusahaan.

Nilai perusahaan dapat dipengaruhi oleh ukuran perusahaan. Penjelasan dari pernyataan ini adalah perusahaan yang dikategorikan sebagai perusahaan besar dan memiliki total aset yang besar dianggap dapat melakukan perkembangan lebih lanjut untuk memajukan perusahaan dan kemudian akan berdampak pada kenaikan keuntungan serta peningkatan pada asetnya. Dengan memiliki aset yang besar perusahaan dianggap mampu melakukan perubahanperubahan untuk lebih memajukan perusahaan. Kemempuan ini akan mempengaruhi pendapa investor mengenai perushaan. Ketika investor melihat adanya perkembangan yang baik datang dari perusahaan tersebut maka investor akan menganggap bahwa perusahaan tersebut memiliki nilai yang bagus. Semakin banyak investor yang merespon positif pada perkembangan yang terjadi pada perusahaan maka semakin banyak calon investor yang inginn berinvestasi pada perusahaan tersebut. Dengan banyaknya respon positif dari investor, memaksimalkan nilai perusahaan akan lebih mudah dicapai. Gill \& Obradovich (2012), Maryam (2014), dan Prasetyorini (2013) dalam penelitian yang dilakukan dan mengangkat topik yang sama menemukan adanya hubungan yang positif antara ukuran perusahaan pada nilai perusahaan.

Tahun 2001 Forum for Corporate Governance in Indonesia menyatakan bahwa yang disebut dengan Good Corporate Governance atau GCG yaitu sistem yang mengendalikan hubungan antara pihak-pihak internal maupun eksternal mengenai kejelasan akan hak dan kewajiban dari pihak-pihak terkait (www.fcgi.org.id). Pengembangan beberapa prinsip yang harus dipenuhi oleh perusahaan dalam penerapan GCG pada perusahaannya dilakukann oleh Organization for Economic Co-operation and Development atau OECD prinsip-prinsip tersebut yaitu yang pertama adalah transparansi, yang kedua adalah pengungkapan, prinsip ketiga adalah kemandirian, prinsip keempat adalah akuntabilitas, yang kelima adalah pertanggungjawaban, dan yang terakhir adalah keadilan (Effendy, 2008). Disebutkan dari keenam prinsip yang harus 
dipenuhi oleh perusahaan yaitu prinsip pertanggungjawaban. Prinsip pertanggungjawaban dapat dipenuhi dengan menaati aturan-aturan yang berlaku mengenai pelaporan keuangan,aturan-aturan yang berlaku mengenai pelaksanaan operasional, dan memberikan pertanggungjawaban kepada masyarakat dan lingkungan (Effendy, 2008). Pertanggungjwaban kepada masyarakat dan lingkungan dapat diwujudkan dengan melakukan kegiatan Corporate Social Responsibility (CSR). CSR merupakan pemberian kontribusi oleh perusahaan pada karyawan, keluarga karyawan serta masyarakat setempat dan publik atau masyarakat umum. Kontribusi yang diberikan dapat berupa upaya perusahaan dalam pembangunan ekonomi bagi pihak-pihak yang telah disebutkan sebelumnya (World Business Council for Sustainable Development). CSR merupakan kewajiban yang harus dilaksanakan oleh perusahaan, bukan lagi kegiatan yang bersifat sukarela (Suwenti et al., 2017).

CSR harus diungkapkan dalam laporan keuangan. Manfaat dari diungkapkannya CSR pada laporan keuangan adalah agar para pengguna informasi laporan keuangan paham tentang hubungan antara aspek ekonomi, lingkungan, dan sosial perusahaan. Pemahaman yang didapatkan oleh pengguna laporan keuangan kemudian akan memudahkannya untuk mengambil suatu keputusan (Bouten et al., 2011). Perusahaan yang mengungkapkan CSR pada laporan keuangannya cenderung mendapaat respon positif dari para investor. Pengungkapan tersebut memiliki dampak pada citra perusahaan. Citra perusahaan yang positif terbentung karena investor mengetahui tentang kegiatan CSR yang dilakukan oleh perusahaan. Citra yang baik ini kemudian akan memberikan semakin banyak respon positif pada investor yang kemudian berdampak pada meningkatnya nilai perushaan. Pada penelitian-penelitian sebelumnya yang dilakukan oleh Retno \& Denies (2012) Utami \& Gunawan (2012) dan Siallagan \& Machfoedz (2006) menemukan adanya hubungan positif antara GCG dan pengungkapan CSR. Sedangkan Junitasari (2015) Tjia \& L. (2015) dan Wiguna (2015) tidak menemukan adanya hubungan antara GCG dan pengungkapan CSR.

Teori sinyal (signalling theory) memberikan penjelasan mengenai alasan dibalik inisiatif dari manajemen perusahaan dalam menyajikan dan melaporkan segala informasi-informasi mengenai perusahaan kepada pasar modal secara sukarela tanpa adanya ketentuan yang menyatakan bahwa pemberiann informasi-informasi tersebut merupakan kewajiban dari perusahaan. Legitimasi yaitu hubungan antara perusahaan dengan masyarakat dimana masyarakat memberikan sesuatu yang dicari atau diinginkan oleh perusahaan kepada perusahaan (Suchman, 1995). Sistem perusahaan dengan legitimasi berarti perusahaan mengatur sistem dalam perusahaannya dengan orientasi bahwa perusahaan tersebut berpihak kepada masyarakat (Gray et al, 1996).

Salah satu tujuan jangka panjang perusahaan adalah memaksimalkan nilai perusahaan. Harga pasar dapat menjadi salah satu pengukuran nilai perusahaan, karena harga pasar perusahaan mencerminkan penilaian investor atas keseluruhan ekuitas yang dimiliki (Suwenti et al., 2017). GCG merupakan sistem pengendalian internal yang dibentuk oleh perusahaan untuk mencapai tujuan yang telah ditentukan oleh perusahaan (Effendy, 2008). Forum for Corporate Governance in Indonesia pada tahun 2001 menyatakan bahwa yang 
disebut dengan Good Corporate Governance atau GCG yaitu sistem yang mengendalikan hubungan antara pihak-pihak internal maupun eksternal mengenai kejelasan akan hak dan kewajiban dari pihak-pihak terkait (www.fcgi.org.id).

Total aset dari suatu perusahaan menjadi tolak ukur dari ukuran perusahaan. Ketika suatu perusahaan tersebut memiliki total aset dalam jumlah yang besar maka perusahaan tersebut termasuk dalam perusahaan yang ukuranya besar. Ketika suatu perusahaan memiliki total aset yang sangat kecil maka perusahaan tersbut dikategorikan sebagai perusahaan yang berukuran kecil. Perusahaan dengan total aset yang berjumlah besar memiliki pertimbangan mengenai penggunaan dananya yang diharapkan kedepannya dapat memberikan efek positif pada nilai perusahaan.

Dalam suatu perusahaan terdapat pemberi wewenang atau principal dan agent yaitu yang diberikan wewenang mengenai kelangsungan hidup suatu perusahaan. Principal dan agent haruslah memiliki visi,misi dan tujuan yang sama mengenai perusahaan. Namun terkadang terdapat konflik kepentingan dimana agent tidak lagi memiliki visi,misi dan tujuan yang sama dengan principal. Konflik ini disebut dengan konflik keagenan. Agent cenderung mengetahui lebih banyak informasi mengenai perusahaan jika dibandingkan dengan principal.

Ketidaksamaan pengetahuan mengenai informasi perusahaan ini disebut dengan asimetri informasi. Dengan adanya konflik keagenan dan asimetri informasi, akan sulit bagi principal untuk mempercayai kinerja dari agent. Konflik ini jika berlangsung dalam jangka panjang akan menghambat usaha perusahaan untuk mencapai pemaksimalan pada nilai perusahaan. Konflik ini dapat diatasi dengan GCG. GCG memberikan fasilitas yaitu kejelasan mengenai prosedur, struktur serta wewenang dalam suatu perusahaan. GCG mengharuskan perusahaan untuk menerapkan prinsip-prinsip yaitu yang pertama adalah transparansi, yang kedua adalah pengungkapan, prinsip ketiga adalah kemandirian, prinsip keempat adalah akuntabilitas, yang kelima adalah pertanggungjawaban, dan yang terakhir adalah keadilan (Veronica \& Sumin, 2010). Menurut Bauer et al. (2004), Retno \& Denies (2012) dan Siallagan \& Machfoedz (2006) dalam penelitiannya yang dilakukan menemukan adanya hubungan yang positif antara GCG dan nilai perusahaan.

$\mathrm{H}_{1}$ : Penerapan GCG berpengaruh positif pada nilai perusahaan

Pertanggungjwaban kepada masyarakat dan lingkungan dapat diwujudkan dengan melakukan kegiatan Corporate Social Responsibility (CSR). CSR merupakan pemberian kontribusi oleh perusahaan pada karyawan, keluarga karyawan serta masyarakat setempat dan publik atau masyarakat umum. Kontribusi yang diberikan dapat berupa upaya perusahaan dalam pembangunan ekonomi bagi pihak-pihak yang telah disebutkan sebelumnya (World Business Council for Sustainable Development).

CSR harus diungkapkan dalam laporan keuangan. Pemahaman yang didapatkan oleh pengguna laporan keuangan setelah melihat pengungkpan CSR kemudian akan memudahkannya untuk mengambil suatu keputusan Bouten et al. (2011) Perusahaan yang mengungkapkan CSR pada laporan keuangannya cenderung mendapaat respon positif dari para investor. Pengungkapan tersebut 
memiliki dampak pada citra perusahaan. Citra perusahaan yang positif terbentung karena investor mengetahui tentang kegiatan CSR yang dilakukan oleh perusahaan. Citra yang baik ini kemudian akan memberikan semakin banyak respon positif pada investor yang kemudian berdampak pada meningkatnya nilai perushaan. Penelitian sebelumnya dilakukan oleh Utami \& Gunawan (2012) dan Retno \& Denies (2012) menemukan adanya hubungan yang positif antara CSR pada nilai perusahaan.

$\mathrm{H}_{2}$ : Pengungkapan CSR berpengaruh positif pada nilai perusahaan.

Nilai perusahaan dapat dipengaruhi oleh ukuran perusahaan. Penjelasan dari pernyataan ini adalah perusahaan yang dikategorikan sebagai perusahaan besar dan memiliki total aset yang besar dianggap dapat melakukan perkembangan lebih lanjut untuk memajukan perusahaan dan kemudian akan berdampak pada kenaikan keuntungan serta peningkatan pada asetnya. Dengan memiliki aset yang besar perusahaan dianggap mampu melakukan perubahanperubahan untuk lebih memajukan perusahaan. Kemempuan ini akan mempengaruhi pendapa investor mengenai perushaan. Ketika investor melihat adanya perkembangan yang baik datang dari perusahaan tersebut maka investor akan menganggap bahwa perusahaan tersebut memiliki nilai yang bagus. Dengan banyaknya respon positif dari investor, memaksimalkan nilai perusahaan akan lebih mudah dicapai.

Menurut Sujoko \& Soebiantoro (2007) perusahaan yang dikategorikan sebagai perusahaan besar cenderung melakukan pengembangan terhadap perusahaan sehingga investor melihat hal tersebut sebagai hal positif dan respon positif yang diberikan investor kemudian dapat berdampak pada meningkatnya nilai perusahaan. Gill \& Obradovich (2012), Prasetyorini (2013), dan Maryam (2014) dalam penelitian yang dilakukan sebelumnya menemukan hubungan positif antara ukuran perusahaan pada nilai perusahaan.

$\mathrm{H}_{3}$ : Ukuran perusahaan berpengaruh positif pada nilai perusahaan

\section{METODE PENELITIAN}

Objek penelitian ini adalah nilai perusahaan yang diukur dengan Price Book Value (PBV) pada perusahaan di Bursa Efek Indonesia yang mengikuti pemeringkatan CGPI periode 2013-2016. Variabel terikat dalam penelitian ini adalah nilai perusahaan sebagai Y. Variabel bebas dalam penelitian ini adalah ukuran perusahaan sebagai $X_{1}$, penerapan GCG sebagai $X_{2}$ dan pengungkapan CSR sebagai $X_{3}$.

Nilai perusahaan dapat dipengaruhi oleh ukuran perusahaan. Penjelasan dari pernyataan ini adalah perusahaan yang dikategorikan sebagai perusahaan besar dan memiliki total aset yang besar dianggap dapat melakukan perkembangan lebih lanjut untuk memajukan perusahaan dan kemudian akan berdampak pada kenaikan keuntungan serta peningkatan pada asetnya. Dengan memiliki aset yang besar perusahaan dianggap mampu melakukan perubahanperubahan untuk lebih memajukan perusahaan. Kemempuan ini akan mempengaruhi pendapa investor mengenai perushaan. Ketika investor melihat adanya perkembangan yang baik datang dari perusahaan tersebut maka investor akan menganggap bahwa perusahaan tersebut memiliki nilai yang bagus. Nilai perusahaan diukur dengan PBV. PBV mengukur nilai perusahaan berdasarkan 
perbandingan harga pasar saham dengan nilai buku ekuitasnya.

Pada tahun 2001 Forum for Corporate Governance in Indonesia menyatakan bahwa yang disebut dengan Good Corporate Governance atau GCG yaitu sistem yang mengendalikan hubungan antara pihak-pihak internal maupun eksternal mengenai kejelasan akan hak dan kewajiban dari pihak-pihak terkait (Effendy, 2008). Good corporate governance dalam penelitian ini diproksikan dengan skor CGPI.

Penelitian ini mengukur pengungkapan CSR dengan menggunakan Corporate Social Responsibility Index (CSRI) berdasarkan standar pelaporan internasional atau sustainability reporting guidelines G-4 yang dikeluarkan oleh Global Reporting Initiative (GRI) pada tahun 2013.

Total aset dari suatu perusahaan menjadi tolak ukur dari ukuran perusahaan. Ketika suatu perusahaan tersebut memiliki total aset dalam jumlah yang besar maka perusahaan tersebut termasuk dalam perusahaan yang ukuranya besar. Ketika suatu perusahaan memiliki total aset yang sangat kecil maka perusahaan tersbut dikategorikan sebagai perusahaan yang berukuran kecil. Perusahaan dengan total aset yang berjumlah besar memiliki pertimbangan mengenai penggunaan dananya yang diharapkan kedepannya dapat memberikan efek positif pada nilai perusahaan (Suwito et al., 2005). Ukuran perusahaan dihitung dengan melihat total aset dari perusahaan yang diteliti (Ghozali \& Chairi., 2016)

Peneliti menggunakan laporan keuangan tahunan, laporan berkelanjutan perusahaa dan skor CGPI sebagai data kuantitatif. Data yang digunakan ini bersifat sekunder dimana data-data ini bersumber dari web resmi BEI yaitu www.idx.co.id dan majalah SWA edisi 24, edisi 25, edisi 26, dan edisi 27. Semua perusahaan yang terdaftar di BEI selama periode 2013-2016 dan termasuk dalam sektor perusahaan manufaktur merupakan populasi dari penelitian. Sampel yang didapatkan setelah menggunakan metode purposive sampling adalah sebanyak 41 sampel dengan kriteria yang pertama, perusahaan go-public yang terdaftar di Bursa Efek Indonesia periode 2013-2016. Kedua, erusahaan yang mengikuti pemeringkatan CGPI periode 2013-2016. Dan ketiga, erusahaan yang melaporkan sustainable report berdasarkan standar GRI G-4 periode 2013-2016.

\section{HASIL DAN PEMBAHASAN}

Objek penelitian yang digunakan dalam penelitian ini adalah perusahaan publik yang terdaftar di Bursa Efek Indonesia (BEI) dan mengikuti pemeringkatan Corporate Governance Perception Index (CGPI). BEI merupakan pasar modal yang ada di Indonesia dan memiliki peran penting dalam perekonomian Indonesia yaitu berupa fungsi ekonomi dan fungsi keuangan. Sementara itu, CGPI merupakan program riset yang diselenggarakan oleh The Indonesian Institute of Corporate Governance (IICG) untuk melakukan pemeringkatan penerapan tata kelola perusahaan yang baik pada perusahaan publik di Indonesia. Pemeringkatan ini akan membagi perusahaan menjadi tiga kategori yaitu, paling terpercaya (most trusted company), terpercaya (trusted company), dan cukup terpercaya (fair trusted company) pada perusahaan yang telah mendaftarkan diri secara sukarela pada program ini agar kemudian memperoleh skor CGPI. 
Tabel 1. Kriteria Pemilihan Sampel

\begin{tabular}{llc}
\hline No. & \multicolumn{1}{c}{ Kriteria } & Jumlah \\
\hline 1 & Perusahaan go-public yang terdaftar di BEI periode 2013-2016 & 535 \\
2 & Perusahaan yang tidak masuk dalam pemeringkatan CGPI periode & $(509)$ \\
& 2013-2016 & $(8)$ \\
3 & Perusahaan tidak melaporkan sustainable report berdasarkan standar & 18 \\
& GRI G-4 & 54 \\
Jumlah perusahaan yang terpilih sebagai sampel & $(13)$ \\
Jumlah sampel perusahaan selama tiga tahun penilitian & 41 \\
Outlier Data & \\
Total sampel dalam tiga tahun penelitian
\end{tabular}

Sumber: Data Penelitian, 2019

Outlier adalah kasus atau data yang memiliki karekterestik unik yang terlihat sangat berbeda jauh dari observasi-observasi lainnya dan muncul dalam bentuk nilai ekstrim baik untuk sebuah variabel tunggal atau variabel kombinasi. Ada empat penyebab timbulnya data outlier antara lain; (1) Kesalahan dalam meng-entri data, (2) Gagal mengspesifikasi adanya missing value dalam program komputer, (3) Outlier bukan merupakan anggota populasi yang kita ambil sebagai sampel, (4) Outlier berasal dari populasi yang kita ambil sebagai sampel, tetapi distribusi dari variabel dalam populasi tersebut memiliki nilai ekstrim dan tidak terdistribusi secara normal. Pada penelitian ini outlier yang terjadi disebabkan oleh adanya nilai ekstrem . Nilai ekstrem ini menyebabkan nilai uji tidak lolos uji autokorelasi. Outlier data yang terdapat pada penelitian ini terdapat 13 sampel data perusahaan harus dikeluarkan dari sampel penelitian ini dikarenakan keseluruhan datanya membuat distribusi data penelitian menjadi tidak normal.

Statistik deskriptif digunakan untuk memberikan deskripsi suatu data yang dilihat dari rata-rata (mean), standar deviasi (standard deviation), dan maksimum-minimum. Rata-rata digunakan untuk memperkirakan besar ratarata populasi yang diperkirakan dari sampel. Standar deviasi digunakan untuk menilai disperse rata-rata dari sampel. Maksimum-minimum digunakan untuk melihat nilai maksimum dan minimum dari populasi.

Tabel 2. Hasil Statistik Deskriptif

\begin{tabular}{lrrrrr}
\hline & N & Minimum & Maximum & Mean & Std. Deviation \\
\hline GCG & 41 & 69.75 & 93.30 & 85.7244 & 4.31741 \\
CSR & 41 & .15 & .96 & .3688 & .18414 \\
Ln_Aset & 41 & 14.65 & 20.76 & 18.1724 & 1.85016 \\
PBV & 41 & -1.59 & 5.01 & 2.0107 & 1.25709 \\
Valid N (listwise) & 41 & & & & \\
\hline
\end{tabular}

Sumber: Data Penelitian, 2019

Variabel GCG dalam penelitian ini diukur menggunakan skor CGP. Berdasarkan Tabel 4.2, nilai rata-rata CGPI sebesar 85,7244 mendekati nilai maksimal sebesar 93,30. Artinya, adanya kecendrungan rata-rata perusahaan sudah baik dalam menerapkan GCG. Nilai deviasi standar GCG sebesar 4,31741 lebih rendah dibandingkan dengan nilai rata rata, artinya sebaran data GCG sudah merata atau perbedaan data satu dengan data yang lainnya tidak tergolong tinggi. Nilai CGPI terendah sebesar 69,75 dimiliki oleh PT Bakrie and 
Brothers Tbk pada tahun 2015, menunjukkan masih terdapat perusahaan yang belum menerapkan GCG dengan baik. Nilai tertinggi CGPI sebesar 93,30 dimiliki oleh PT Bank Mandiri (Persero) Tbk pada tahun 2016, menunjukkan perusahaan sudah menerapkan GCG dengan maksimal.

Variabel CSR dalam penelitian ini diukur menggunakan Corporate Social Responsibilty Index (CSRI) berdasarkan kerangka indikator GRI-G4. Berdasarkan Tabel 4.2 nilai rata-rata CSRI sebesar 0,3688 mendekati nilai minimum sebesar 0,15 . Artinya, ada kecendrungan rata-rata perusahaan belum menerapkan CSR dengan baik. Nilai deviasi standar CSR sebesar 0,18414 lebih rendah daripada nilai rata-ratanya, artinya sebaran data CSR sudah merata atau perbedaan data satu dengan data yang lainnya tidak tergolong tinggi. Nilai CSRI terendah sebesar 0,15 dimiliki oleh PT Bank Central Asia Tbk pada tahun 2015, menunjukkan masih terdapat perusahaan yang belum melakukan pengungkapan CSR dengan maksmimal. Nilai tertinggi CSRI sebesar 0,96 dimiliki PT Tambang Batubara Bukit Asam Tbk pada tahun 2015, menunjukkan perusahaan sudah melakukan pengungkapan dengan maksimal.

Variabel ukuran perusahaan disini diukur dengan menggunakan Total asset (Ln_asset). Berdasarkan table 4.2 nilai rata-rata ukuran perusahaan 18,1724 mendekati nilai maximum sebesar 20,76 artinya adanya kecendrungan rata-rata perusahaan sudah baik dalam menetapkan ukuran perusahaan. Nilai devisiasi standar ukuran perusahaan sebesar 1.85016 lebih rendah dari nilai rata-ratanya, artinya sebaran data ukuran perusahaan sudah merata atau perbedaan data satu dengan data yang lainnya tidak tergolong tinggi. Nilai total asset terendah sebesar 14,65 dimiliki oleh PT Bakrie and Brothers Tbk pada tahun 2015, menunjukan masih ada perusahaan yang belum menjalankan ukuran perusahaan dengan maksimal. Nilai tertinggi dari total asset sebesar 20,76 dimiliki oleh PT Bank Mandiri (Persero) Tbk, menunjukan perusahaan sudah menetapkan ukuran perusahaan dengan baik.

Variabel nilai perusahaan dalam penelitian ini diukur menggunakan rasio price book value (PBV). Berdasarkan Tabel 4.2, nilai rata-rata PBV sebesar 2,0107 mendekati nilai maksimal sebesar 5,01, artinya rata-rata perusahaan memiliki kinerja yang baik dan mampu meningkatkan nilai perusahaan. Nilai standar deviasi atas nilai perusahaan sebesar 1,25709 nilai ini lebih rendah dibandingkan nilai rata-rata. Hal ini menunjukkan bahwa sebaran data nilai perusahaan sudah merata atau perbedaan data satu dengan data yang lainnya tidak tergolong tinggi. Nilai minimum sebesar -1,59 dimiliki oleh PT Bakrie \& Brothers Tbk. pada tahun 2015, nilai perusahaan negatif dapat mengindikasikan bahwa kualitas dan kinerja fundamental perusahaan tersebut menurun, sementara nilai maksimum sebesar 5,01 dimiliki oleh PT Bank Central Asia Tbk. pada tahun 2016, dapat dikatakan bahwa perusahaan tersebut sudah mampu meningkatkan kualitas dan kinerja fundamentalnya.

Uji Normalitas adalah suatu pengujian yang digunakan untuk mengetahui apakah model regresi, variabel dependen dan variabel independen atau keduanya mempunyai distribusi normal atau tidak. Model regresi yang baik adalah mempunyai distribusi data normal atau mendekati normal. Uji normalitas digunakan untuk menguji dalam model regresi variabel pengganggu atau nilai residual memiliki distribusi normal agar uji statistik untuk jumlah sampel kecil 
hasilnya tetap valid (Ghozali \& Chairi., 2016).

\section{Tabel 3. Hasil Uji Normalitas}

Kolmogorov-Smirnov Z

$$
\mathrm{N}
$$

$\begin{array}{lll} & \text { GCG } & 0,247 \\ \text { Asymp.Sig.(2-taled) } & \text { CSR } & 0,163 \\ & \text { Ln_Aset } & 0,314 \\ & \text { PBV } & 0,553\end{array}$

41

247

314

0,553
Unstandardized Residual

\section{Sumber: Data Penelitian, 2019}

Berdasarkan tabel 3, nilai Asymp. Sig (2-tailed) masing-masing variabel adalah lebih besar daripada 0,05. Hasil ini memiliki arti bahwa data-data yang digunakan dalam penelitian telah berdistribusi normal.

Uji multikolinieritas adalah pengujian yang bertujuan untuk menguji model apakah dalam model regresi ditemukan adanya kolerasi antarvariabel independen. Untuk mendeteksi ada atau tidaknya multikolinieritas di dalam model regresi dalam penelitian ini dengan melihat tolerance, dan variance inflation factor (VIF). Hasil nilai tolerance yang nilainya lebih besar dari 0,10 dan VIF yang besarnya kurang dari 10 mengindikasikan tidak adanya gejala multikolinieritas.

Tabel 4. Hasil Uji Multikolinieritas

\begin{tabular}{lcc}
\hline \multicolumn{1}{c}{ Variabel } & Tolerance & VIF \\
\hline Good Corporate Governance $\left(\mathrm{X}_{1}\right)$ & 0,989 & 1,011 \\
Corporate Social Responsibility $\left(\mathrm{X}_{2}\right)$ & 0,986 & 1,014 \\
Ukuran Perusahaan $\left(\mathrm{X}_{3}\right)$ & 0,984 & 1,016 \\
\hline
\end{tabular}

Sumber: Data Penelitian, 2019

Setelah dilakukan uji multikolinearitas dengan tujuan mendapatkan hasil nilai tolerance yang melebihi 10 persen dan juga nilai VIF kurang dari 10, didapatkan hasil dari uji multikolinearitas untuk setiap variabel bebas yang digunakan berhasil mendapatkan nilai tolerance yang melebihi 10 persen dan juga nilai VIF yang kurang dari 10. Hasil ini menandakan bahwa model yang digunakan terbebas dari masalah multikolinearitas.

Autokorelasi bertujuan untuk menguji apakah dalam suatu model regresi linier ada korelasi antara kesalahan penggangu pada periode $t$ dengan kesalahan pada periode $\mathrm{t}-1$ (sebelumnya). Jika terjadi korelasi maka dikatakan ada autokorelasi. Autokorelasi muncul karena observasi yang berurutan sepanjang waktu berkaitan satu sama lain. Model regresi yang baik adalah yang bebas dari autokorelasi. Untuk mendeteksi ada atau tidaknya autokorelasi dapat digunakan dengan uji Durbin Watson (D-W)

Tabel 5. Hasil Uji Autokorelasi

\begin{tabular}{cccccc}
\hline No & $\mathrm{dl}$ & $\mathrm{Du}$ & $4-\mathrm{du}$ & $\mathrm{DW}$ & Simpulan \\
\hline 1 & 1,3480 & 1,6603 & 2,3397 & 1,794 & Bebas autokorelasi \\
\hline
\end{tabular}

Sumber: Data Penelitian, 2019

Setelah dilakukan uji autokorelasi dengan tujuan mendapatkan nilai Durbin Watson atau nilai dw yang melebihi nilai du dan juga kurang atau sama dengan nilai 4-du, didapatkan hasil nilai dw sebesar 1,794. Nilai dw ini melebihi 
nilai du yang telah ditetapkan yaitu sebesar 1,6603 dan juga lebih kecil dari 4-du yaitu 2,3397. Hasil ini menunjukkan tidak adanya autokorelasi antar residual.

Uji heterokedastisitas digunakan untuk menguji apakah dalam sebuah model regresi berganda terjadi ketidaksamaan varians dari residual satu pengamatan ke pangamatan yang lain. Jika varians residual dari sebuah pengamatan ke pengamatan yang lain tetap, maka disebut homoskedastisitas dan jika berbeda disebut heterokedastisitas. Cara untuk mendeteksi adanya heterokedastisitas yaitu dengan melakukan uji glejser, jika variabel independen signifikan secara statistik memengaruhi variabel dependen maka ada indikasi terjadinya heteroskedastisitas.

Tabel 6. Hasil Uji Heterokedastisitas

\begin{tabular}{lcc}
\hline Variabel & Sig. & Keterangan \\
\hline Good Corporate Governance $\left(\mathrm{X}_{1}\right)$ & 0,799 & Bebas heteroskedasitas \\
Corporate Social Responsibility $\left(\mathrm{X}_{2}\right)$ & 0,096 & Bebas heteroskedasitas \\
Ukuran Perusahaan $\left(\mathrm{X}_{3}\right)$ & 0,855 & Bebas heteroskedasitas \\
\hline
\end{tabular}

Sumber: Data Penelitian, 2019

Setelah dilakukan uji heteroskedastisitas dengan tujuan mendapatkan hasil nilai signifikansi yang melebihi 0,05, didapatkan hasil dari uji heteroskedastisitas untuk setiap variabel bebas yang digunakan berhasil mendapatkan nilai signifikansi yang melebihi 0,05 . Hasil ini menandakan bahwa model yang digunakan terbebas dari masalah heteroskedastisitas.

Teknik analisis data yang digunakan didalam penelitian ini dilakukan dengan menggunakan analisis regresi berganda. Analisis regresi berganda pada dasarnya adalah studi mengenai ketergantungan variabel terikat atau dependen dengan satu atau lebih variabel bebas atau independen, dengan tujuan untuk mengestimasi atau memprediksi rata-rata populasi atau nilai rata-rata variabel dependen berdasarkan nilai variabel indipenden yang diketahui. Pengujian pada hipotesis baik secara parsial dan simultan, dilakukan setelah model regresi yang digunakan bebas dari pelanggaran asumsi klasisk. Tujuannya adalah agar hasil penelitian dapat diinterpretasikan secara tepat dan efisien. Dalam penelitian ini teknik analisis regresi linier berganda digunakan untuk mengetahui pengaruh variabel independen berupa penerapan mekanisme GCG dan pengungkapan CSR pada variabel dependen berupa nilai perusahaan.

Tabel 7. Hasil Analisis Regresi Linear Berganda

\begin{tabular}{|c|c|c|c|c|c|c|}
\hline \multirow{2}{*}{\multicolumn{2}{|c|}{ Model }} & \multicolumn{5}{|c|}{ Standardized } \\
\hline & & $B$ & Std. Error & Beta & $\mathrm{t}$ & Sig. \\
\hline \multirow[t]{4}{*}{1} & (Constant) & .286 & .167 & & 1.710 & .096 \\
\hline & GCG & . 328 & . 158 & 302 & 2.075 & .045 \\
\hline & CSR & 236 & . 160 & 215 & 1.472 & .149 \\
\hline & Ln_Aset & .364 & .173 & .307 & 2.101 & .043 \\
\hline
\end{tabular}

Sumber: Data Penelitian, 2019

Dari hasil analisis regresi linear berganda pada Tabel 7 dapat dibuat persamaan sebagai berikut:

$$
\mathrm{Y}=0,286+0,328 \mathrm{X} 1+0,326 \mathrm{X} 2+0,364 \mathrm{X} 3+\varepsilon
$$

Nilai a sebesar 0,286 berarti apabila $X_{1}, X_{2}$ dan $X_{3}$ bernilai 0 , maka nilai perusahaan adalah sebesar 0,286 satuan. Nilai $\beta_{1}$ sebesar 0,328 berarti apabila $X_{1}$ meningkat sebesar 1 satuan dengan anggapan variabel lainnya konstan, maka $Y$ 
akan meningkat sebesar 0,328 satuan. Nilai $\beta_{2}$ sebesar 0,236 berarti apabila $X_{2}$ meningkat sebesar 1 satuan dengan anggapan variabel lainnya konstan, maka $Y$ akan meningkat sebesar 0,236 satuan. Nilai $\beta_{3}$ sebesar 0,364 berarti apabila $X_{3}$ meningkat sebesar 1 satuan dengan anggapan variabel lainnya konstan, maka $Y$ akan meningkat sebesar 0,364 satuan.

Tabel 8. Hasil Uji F

\begin{tabular}{llrrrrr}
\hline Model & & Sum of Squares & df & Mean Square & F & Sig. \\
\hline 1 & Regression & 9.530 & 3 & 3.177 & 3.558 & $0.023^{\mathrm{a}}$ \\
& Residual & 33.036 & 37 & .893 & & \\
& Total & 42.566 & 40 & & & \\
\hline
\end{tabular}

Sumber: Data Penelitian, 2019

Hasil uji $\mathrm{F}$ ( $F$ test) pada Tabel 8 menunjukkan bahwa nilai $\mathrm{F}$ hitung sebesar 3,558 dengan nilai signifikansi $P$ value 0,023 yang lebih kecil dari $\alpha=0,05$, ini berarti model yang digunakan pada penelitian ini adalah layak. Hasil ini memberikan makna bahwa seluruh variabel independen yaitu Penerapan GCG, Pengungkapan CSR, dan Ukuran perusahaan tepat memprediksi atau menjelaskan fenomena Nilai perusahaan di BEI periode 2013-2016. Dengan kata lain, Penerapan GCG, Pengungkapan CSR, dan ukuran perusahaan secara simultan berpengaruh signifikan pada nilai perusahaan.

Tabel 9. Hasil Uji Koefisien Determinasi

\begin{tabular}{ccccc}
\hline Model & $R$ & $R$ Square & Adjusted $R$ Square & $\begin{array}{c}\text { Std. Error of the } \\
\text { Estimate }\end{array}$ \\
\hline 1 & $0,473^{a}$ & 0,224 & 0,161 & 0,94491168 \\
\hline
\end{tabular}

Sumber: Data Penelitian, 2019

Setelah dilakukan uji koefisien determinasi, hasil yang didapatkan adalah denga nilai $R^{2}$ 0,161 maka disimpulkan bahwa sebesar 16,1 persen dari $\mathrm{X}_{1}, \mathrm{X}_{2}$ dan $\mathrm{X}_{3}$ dapat menjelaskan variasi variabel Y. Sisanya yaitu sebesar 83,9 persen dijelaskan oleh variabel lain yang tidak digunakan dalam model penelitian ini.

Berdasarkan hasil analisis pengaruh Penerapan GCG terhadap Nilai perusahaan pada Tabel 9 diperoleh nilai signifikansi sebesar 0,045 dengan nilai koefisien regresi positif sebesar 0,328. Nilai signifikansi 0,045<0,050 mengindikasikan bahwa $\mathrm{H}_{1}$ diterima. Hasil ini mempunyai arti bahwa Penerapan GCG berpengaruh positif pada nilai perusahaan. Pengaruh positif yang dimaksud adalah ketika perusahaan menerapkan GCG dengan baik maka akan berdampak pada peningkatan nilai perusahaan. Perusahaan yang menerapkan GCG dengan baik dianggap memiliki pengendalian internal yang baik sehingga menghindari perilaku menyimpang yang kemungkinan akan dilakukan oleh manajemen. CGPI menjadi salah satu faktor yang menjadi pertimbangan investor ketika akan menginvestasikan dananya pada suatu perusahaan. Dengan melihat CGPI investor memiliki pertimbangan dalam menentukan suatu keputusan dalam berinvestasi Bauer et al. (2004), Siallagan \& Machfoedz (2006) serta Retno \& Denies (2012) dalam penelitian yang dilakukannya menemukan adanya hubungan positif antara GCG pada nilai perusahaan.

Berdasarkan hasil analisis pengaruh Pengungkapan CSR terhadap Nilai perusahaan diperoleh nilai signifikansi sebesar 0,149 dengan nilai koefisien regresi positif sebesar 0,236. Nilai signifikansi 0,149>0,050 mengindikasikan 
bahwa $\mathrm{H}_{2}$ ditolak. Hasil ini mempunyai arti bahwa Pengungkapan CSR tidak berpengaruh pada nilai perusahaan. Pengungkapan CSR tidak memiliki pengaruh pada nilai perusahaan. Ketidaksiapan pasar mengenai komitmen perusahaan dalam melakukan CSR serta pandangan negative investor mengenai kebenaran aktivitas CSR menjadi alasan yang menjadi dasar dari hasil penelitian ini. Terkadang meski telah diungkapkan dalam laporan keuangan, CSR masih belum memberikan informasi yang relevan sehingga belum bisa digunakan oleh investor dalam mengambil suatu keputusan. Cardamone et al., (2012) Tjia \& L (2015), serta Junitasari (2015) dalam penelitian yang dilakukannya juga menemukan tidak adanya hubungan antara pengungkapan CSR pada nilai perusahaan

Berdasarkan hasil analisis pengaruh ukuran perusahaan terhadap Nilai perusahaan pada Tabel 9 diperoleh nilai signifikansi sebesar 0,043 dengan nilai koefisien regresi positif sebesar 0,364. Nilai signifikansi 0,043<0,050 mengindikasikan bahwa $\mathrm{H}_{3}$ diterima. Hasil ini mempunyai arti bahwa ukuran perusahaan berpengaruh pada nilai perusahaan. Kesimpulan dari hasil uji hipotesis ketiga ini adalah semakin besarnya ukuran perusahaan akan berdampak pada peningkatan nilai perusahaan.

Nilai perusahaan dapat dipengaruhi oleh ukuran perusahaan. Penjelasan dari pernyataan ini adalah perusahaan yang dikategorikan sebagai perusahaan besar dan memiliki total aset yang besar dianggap dapat melakukan perkembangan lebih lanjut untuk memajukan perusahaan dan kemudian akan berdampak pada kenaikan keuntungan serta peningkatan pada asetnya. Dengan memiliki aset yang besar perusahaan dianggap mampu melakukan perubahanperubahan untuk lebih memajukan perusahaan. Kemempuan ini akan mempengaruhi pendapa investor mengenai perushaan. Ketika investor melihat adanya perkembangan yang baik datang dari perusahaan tersebut maka investor akan menganggap bahwa perusahaan tersebut memiliki nilai yang bagus. Dengan banyaknya respon positif dari investor, memaksimalkan nilai perusahaan akan lebih mudah dicapai.

Menurut Sujoko \& Soebiantoro (2007) perusahaan yang dikategorikan sebagai perusahaan besar cenderung melakukan pengembangan terhadap perusahaan sehingga investor melihat hal tersebut sebagai hal positif dan respon positif yang diberikan investor kemudian dapat berdampak pada meningkatnya nilai perusahaan. Gill \& Obradovich (2012), Prasetyorini (2013), dan Maryam (2014) dalam penelitian yang dilakukan sebelumnya menemukan hubungan positif antara ukuran perusahaan pada nilai perusahaan.

Berdasarkan hasil pengujian yang telah dilakukan, penelitian ini memberikan implikasi teoritis bahwa teori signal memberikan pengaruh ukuran perusahaan dan penerapan GCG pada nilai perusahaan, sedangkan teori signal dan legitimasi tidak memberikan pengaruh terhadap pengungkapan CSR. Hasil uji dalam penelitian ini menemukan bahwa ukuran perusahaan dan penerapan GCG pada nilai perusahaan berpengaruh positif pada nilai perusahaan ,sedangkan untuk pengungkapan CSR tidak berpengaruh pada nilai perusahaan. Oleh karenanya sebaiknya perusahaan menerapkan kedua indikator tersebut yaitu ukuran perusahaan dan penerapan GCG dikarnakan dapat menambah nilai dari perusahaa. 


\section{SIMPULAN}

Penerapan GCG berpengaruh positif pada nilai perusahaan. Pengaruh positif yang dimaksud adalah ketika perusahaan menerapkan GCG dengan baik maka akan berdampak pada peningkatan nilai perusahaan. Perusahaan yang menerapkan GCG dengan baik dianggap memiliki pengendalian internal yang baik sehingga menghindari perilaku menyimpang yang kemungkinan akan dilakukan oleh manajemen.

Pengungkapan CSR tidak memiliki pengaruh pada nilai perusahaan. Ketidaksiapan pasar mengenai komitmen perusahaan dalam melakukan CSR serta pandangan negative investor mengenai kebenaran aktivitas CSR menjadi alasan yang menjadi dasar dari hasil penelitian ini.

Ukuran perusahaan memiliki pengaruh yang positif pada nilai perusahaan. ukuran perusahaan berpengaruh pada nilai perusahaan. Kesimpulan dari hasil uji hipotesis ketiga ini adalah semakin besarnya ukuran perusahaan akan berdampak pada peningkatan nilai perusahaan. Ketika investor melihat adanya perkembangan yang baik datang dari perusahaan tersebut maka investor akan menganggap bahwa perusahaan tersebut memiliki nilai yang bagus. Dengan banyaknya respon positif dari investor, memaksimalkan nilai perusahaan akan lebih mudah dicapai.

\section{REFERENSI}

Bauer, R., Guenster, N., \& Otten, R. (2004). Empirical Evidence on Corporate Governance in Europe: The Effect on Stock Returns, Firm Value and Performance. Journal of Asset Management, 5(2), 91-104.

Bouten, L., Everaert, P., van Liedekerke, L., De Moor, L., \& Christiaens, J. (2011). Corporate Social Responsibility Reporting: A Comprehensive Picture., 35(3), 187-204.

Brigham, E. F., \& Housten, J. (2011). Dasar Dasar Manajemen Keuangan (11th ed.). Jakarta: Salemba Empat.

Cardamone, P., Carnevale, C., \& Giunta, F. (2012). The Value Relevance of Social Reporting: Evidence from Listed Italian Companies. Emeraal Journal of Applie Accounting Research, 13(3), 255-269.

Effendy, O. U. (2008). Dinamika Komunikasi. Bandung: PT. Remaja Rosdakarya.

Ghozali, I., \& Chairi. (2016). Teori Akuntansi. Semarang: Badan Penerbit Universitas Diponegoro.

Gill, A., \& Obradovich, J. D. (2012). The Impact of Corporate Governance and Financial Leverage on the Value of American Firms. International Research Journal of Finance and Economics, 91.

Gray, R., Owen, D., \& Adams, C. (1996). Accounting \& accountability: changes and challenges in corporate social and environmental reporting. Prentice Hall.

Harjito, A., \& Martono. (2005). Manajemen Keuangan. Jakarta: Ekonisia.

Junitasari, P. D. K. (2015). Pengaruh Pengungkapan Corporate Social Responsibility dan Good Corporate Governance pada Nilai Perusahaan.

Maryam, S. (2014). Analisis Pengaruh Firm Size, Growth, Leverage, dan Profitabilitas Terhadap Nilai Perusahaan Pada Nilai Perusahaan 
Manufaktur yang Terdaftar Di BEI periode 2008 - 2012. Skripsi. Makassar: Fakultas Ekonomi Dan Bisnis Univesitas Hassanuddin.

Nandasari, K. (2009). Pengaruh Corporate Social Responsibility (CSR) terhadap Nilai Perusahaan (Studi Empiris pada Perusahaan Tambang yang Listing di BEI. Skripsi Sarjana Akuntansi Pada Universitas Negeri Yogyakarta.

Prasetyorini, B. F. (2013). Pengaruh Ukuran Perusahaan, Leverage, Price Earning Ratio dan Profitabilitas terhadap Nilai Perusahaan. Jurnal Ilmu Manajemen, 1(1), 183-196.

Puspaningrum, Y. (2014). Pengaruh Corporate Social Responsibility dan Kepemilikan Manajerial terhadap Nilai Perusahaan dengan Profitabilitas dan Ukuran Perusahaan sebagai Variabel Moderating. Skripsi Sarjana Akuntansi Pada Fakultas Ekonomi Universitas Negeri Yogyakarta.

Retno, R. D. P., \& Denies. (2012). Pengaruh Good Corporate Governance dan Pengungkapan Corporate Social Responsibility terhadap Nilai Perusahaan. Jurnal Nominal, 1(1), 84-103.

Siallagan, H., \& Machfoedz, M. U. (2006). Mekanisme Corporate Governance, Kualitas Laba dan Nilai perusahaan. Simposium Nasional Akuntansi IX. Padang., 23-26.

Suchman, M. C. (1995). Managing legitimacy: Strategic and institutional approaches. Academy of Management Review, 20(3), 571-610.

Sujoko, \& Soebiantoro., U. (2007). Pengaruh Struktur Kepemilikan Saham, Leverage, Faktor Intern Dan Faktor Ekstern Terhadap Nilai Perusahaan (Studi empirik pada perusahaan manufaktur dan non manufaktur di Bursa Efek Jakarta). Jurnal Manajemen Dan Kewirausahaan., 9(1), 41-48.

Suwenti, A., Utomo, S. W., \& Wijaya., A. L. (2017). Pengaruh Pemberdayaan Karyawan, Kepuasan Kerja Dan Dukungan Organisasi Terhadap Komitmen Organisasi Pada PT PLN (Persero) Trans - Jbtb App Madiun. Forum Ilmiah Pendidikan Akuntansi., 5(1), 666-680.

Suwito, Edy, Herawaty, A. (2005). Analisis Pengaruh Karakteristik Perusahaan Terhadap Tindakan Perataan Laba yang Dilakukan oleh Perusahaan yang Terdaftar Di Bursa Efek Jakarta.

Tjia, \& L., S. (2015). Effect of CSR Disclousure to Firm Value: Study For Banking Industry In Indonesia. World Journal of Social Science, 2(6), 169-178.

Utami, S. S., \& Gunawan, B. (2012). Peranan Corporate Social Responsibility dalam Nilai Perusahaan. Jurnal Akuntansi Dan Keuangan, 7(2), 174-185.

Veronica, T. M., \& Sumin, A. (2010). The Effect Of Company CharactheristicOn Disclosure Of Social Responsibility InMining Corporate Sector Listed In Indonesia StockExchange. Jurnal Akuntansi Keuangan, 12(1).

Wiguna, I. P. (2015). Voluntary Disclosure sebagai Pemoderasi Pengaruh antara Good Corporate Governance terhadap Nilai Perusahaan. 